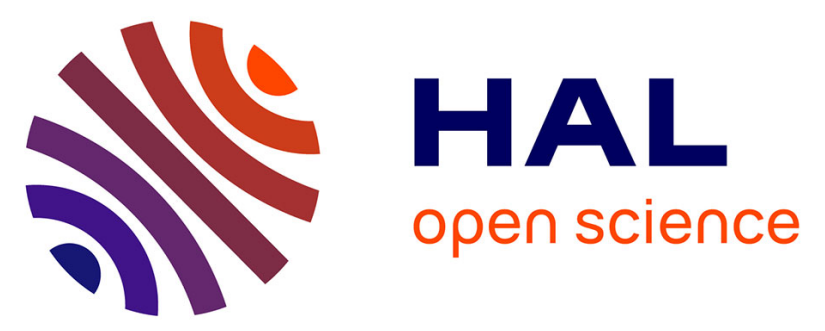

\title{
Economic and social effectiveness of carbon pricing schemes to meet Brazilian NDC targets
}

William Wills, Emilio Lebre La Rovere, Carolina Grottera, Giovanna Ferrazzo Naspolini, Gaëlle Le Treut, F. Ghersi, Julien Lefèvre, Carolina Burle Schmidt Dubeux

\section{- To cite this version:}

William Wills, Emilio Lebre La Rovere, Carolina Grottera, Giovanna Ferrazzo Naspolini, Gaëlle Le Treut, et al.. Economic and social effectiveness of carbon pricing schemes to meet Brazilian NDC targets. Climate Policy, 2022, 22 (1), pp.48-63. 10.1080/14693062.2021.1981212 . hal-03500923

\section{HAL Id: hal-03500923 https://hal.science/hal-03500923}

Submitted on 22 Dec 2021

HAL is a multi-disciplinary open access archive for the deposit and dissemination of scientific research documents, whether they are published or not. The documents may come from teaching and research institutions in France or abroad, or from public or private research centers.
L'archive ouverte pluridisciplinaire HAL, est destinée au dépôt et à la diffusion de documents scientifiques de niveau recherche, publiés ou non, émanant des établissements d'enseignement et de recherche français ou étrangers, des laboratoires publics ou privés. 


\title{
Economic and social effectiveness of carbon pricing schemes to meet Brazilian NDC targets
}

\author{
William Wills, Emilio Lebre La Rovere, Carolina Grottera, Giovanna Ferrazzo Naspolini, Gaëlle Le \\ Treut, Frédéric Ghersi, Julien Lefèvre, Carolina Burle Schmidt Dubeux
}

\section{Abstract}

Curbing GHG emissions while preserving economic growth is one of the main challenges that developing countries are facing to meet the Paris Agreement commitments. Brazil's NDC target aims to reduce economy-wide absolute levels of GHG emissions by $37 \%$ in 2025 and $43 \%$ in 2030, compared to 2005 emissions. In this paper, we compare command-and-control and carbon pricing policies to induce the Brazilian economy to meet its NDC targets. We focus on analysing synergies and trade-offs in macroeconomic and social development, captured by economic growth and income distribution while reducing GHG emissions. By integrating a series of sectoral models and a computable general equilibrium (CGE) model, we develop and run different policy scenarios that simulate a set of carbon pricing schemes in Brazil. Our analysis shows that NDC implementation in Brazil under carbon pricing policies allows the country to meet its targets and improve economic and social indicators compared to a command-and-control policy. With about the same GHG emissions up to 2030, important macroeconomic and social co-benefits can be achieved under a carbon pricing policy in Brazil, allowing for reduced welfare losses against business-as-usual trends.

\section{Key policy insights}

- Carbon pricing policies are more cost-effective to meet NDC targets in Brazil up to 2030, resulting in higher GDP and household income, in comparison to other individual policy instruments, including command-and-control and subsidies to investments.

- A carbon price of about 10 USD/tCO2e, combined importantly with deforestation rates under control, would allow Brazil to meet its NDC targets. 
- Recycling carbon pricing revenues can help soften the burden on the labour market and protect low-income households from welfare losses.

\section{Introduction}

The Brazilian NDC to the UNFCCC Paris Agreement presents a commitment to reducing economy-wide absolute levels of GHG emissions by 37\% in 2025 and 43\% in 2030, compared to 2005 emissions (Brasil, 2016). In its annex, the document included several actions to reduce CO2e emissions in the country, but the type of instrument to achieve the target was not specified.

The first Brazilian NDC could be considered ambitious as a few years ago the country was one of the first developing countries to present an economy-wide, absolute target. In December 2020, Brazil submitted an updated first NDC reinforcing the 2025 target and confirming the 2030 one (Brasil, 2020). Also, the document mentions an indicative target of reaching carbon neutrality by 2060 . Unfortunately, this revised NDC effectively weakens climate action targets for 2025 and 2030 because it is based on the updated 2005 inventory (with higher base year emission levels). In practice, Brazilian emissions in 2030 could be up to 400 MtCO2e higher. Climate Action Tracker (CAT, 2021) rated the second Brazilian NDC as "highly insufficient".

Since 2012, deforestation rates in the Amazon region have been rising, and the rise has accelerated in recent years (INPE, 2021). This suggests that Brazil lacks a clear strategy for the conservation of the Amazon region (Mataveli et al., 2021).

Command and control and other instruments have been widely used in Brazil to promote reductions in GHG emissions since 2009 (when Brazil presented its first targets at COP15 in Copenhagen). Yet, economic theory states that carbon pricing instruments would minimise climate mitigation costs. In addition, it is widely recognised that the essential purpose of such a price signal is to drive economic behaviour in the medium- and long-term.

The research described here was carried out to respond to the demand from the World Bank's Partnership for Market Readiness in Brazil (PMR) ${ }^{1}$. We simulate two carbon pricing scenarios designed to meet the Brazilian NDC targets: (i) Emissions Pricing Scenario (basic pricing scheme), (ii) Distributive Scenario (alternative carbon revenue recycling scheme, aimed at protecting lower-income households' welfare). We contrast the results from these carbon pricing scenarios with the Reference Scenario, in

\footnotetext{
1 https://www.thepmr.org/.
} 
which the Brazilian targets are also achieved, but through command-and-control, subsidies to investments and other policy instruments reflecting the mitigation measures listed in the NDC Annex (Brasil, 2016). The objective is to carry out comparative analysis across the different scenarios and identify if carbon pricing would prove more cost-efficient and beneficial from a socioeconomic perspective for the country to reach its NDC. We present and discuss indicators such as GDP, GDP per capita, trade balance, unemployment rate, households' income levels, and income distribution.

Carbon pricing instruments, such as a carbon tax or a carbon market, have not yet been implemented in Brazil for several reasons, including the uncertainty regarding the impacts of these instruments, and the lack of political will, among others. This research contributes to the literature by testing the effects of different carbon pricing schemes in achieving NDC goals while comparing macroeconomic and social indicators. The research provides relevant evidence to the Brazilian government and stakeholders on the performance of alternative climate change mitigation policies for the country to reconcile both climate objectives and socioeconomic development in Brazil.

This paper is structured as follows: Section 2 presents a detailed literature review on carbon pricing policy and model scenarios for Brazil. Section 3 describes the methods, models and data sources used to carry out our analysis, as well as the scenarios' assumptions and storylines. Section 4 presents the main modelling results, macroeconomic and social indicators, and GHG emissions levels. Section 5 provides a discussion of our key results and policy implications. Section 6 summarises the main findings.

\section{Literature review}

Carbon pricing is thought to minimise the cost of reducing emissions (compared to command-andcontrol policies, for example) in the absence of other market failures (Boyce, 2018). By modelling the economy-wide relationships between economic agents and sectors, computable general equilibrium (CGE) models are the most commonly used empirical tools to analyse all major issues related to carbon pricing (Timilsina, 2018). Most CGE studies show that carbon pricing incurs net economic costs in terms of GDP or household welfare (in addition to the benefits of climate change mitigation and other cobenefits) (Frey, 2017; Karapinar et al., 2019; Van Heerden et al., 2016; Zhang et al., 2016; MozChristofoletti and Pereda, 2021 for recent examples). Exemptions for certain sectors or actors increase the carbon price and the overall cost to reach any given emission target (Böhringer and Rutherford, 1997; Meng et al., 2013; Van Heerden et al., 2006). 
As carbon pricing generates government revenue, the gross cost of carbon pricing can be significantly reduced by recycling carbon revenues into the economy. Main recycling schemes include lump-sum transfers to households, reducing existing taxes, financing infrastructure or subsidising low carbon technologies. The literature shows that reducing existing taxes cuts down mitigation costs more than lump-sum transfers in most cases (McKitrick, 1997; Timilsina and Shrestha, 2007). In certain situations, a 'strong double dividend' can even occur (Goulder, 2013), but there is no generalisable result either on the conditions for a double dividend or on which type of (pre-existing) tax is best to cut; contextspecific empirical analysis is required (Freire-González, 2018).

Carbon pricing raises concerns about distributional impacts across households as direct impacts are most often regressive (Williams et al., 2014). However, recycling carbon revenues through lump-sum transfers or other transfers targeting the poorest households can alleviate this impact and even reverse it to create progressive impacts in some cases (Rausch et al., 2011). Overall, the CGE literature highlights a trade-off between economic efficiency - best achieved by cutting existing taxes - and equity - best achieved by targeted transfers through recycling options (Hourcade et al., 2010; Alton et al., 2014). Eventually, carbon pricing induces risks of competitiveness loss (Böhringer et al., 2017; Lu et al., 2010). Border tax adjustments (BTA) - the taxation of imports at the border in proportion to their carbon footprints - can be used to offset the carbon tax burden weighing on domestic industries. BTA is beneficial for domestic economies (Liang et al., 2016), but could be highly damaging for developing countries if it was generalised at a global scale (Mattoo et al., 2013).

Despite their ability to analyse the key aspects of carbon pricing, CGE models have been criticised for their lack of technical realism. Hybrid modelling approaches have been developed to combine the strengths of sectoral, energy and CGE models (Hourcade et al., 2006). Such hybrid approaches make it possible to improve the technical realism of mitigation options in the context of economy-wide analysis, which proves critical for the assessment of emissions reductions and of the cost impacts of climate policy (Wing, 2006; Lanz and Rausch, 2011; Fujimori et al., 2019; Ghersi and Hourcade, 2006). Several hybrid approaches exist in the literature. A first approach is to directly include technological details as part of the CGE model for key sectors (power generation, transportation, etc.) (Dai et al., 2016; Wing, 2006; Böhringer, 1998; Böhringer and Rutherford, 2008; Lanz and Rausch, 2011). However, this approach faces practical limits to expand in a meaningful way on the detailed representation of technologies and mitigation options for multiple sectors within the CGE model.

An alternative approach is to link standalone CGE with sectoral or energy models through an iterative exchange of variables to capture the key feedbacks, for example, between energy, land-use systems and the economy (Arndt et al., 2016; Drouet et al., 2005; Krook-Riekkola et al., 2017). This approach 
makes it possible to build on the richness and details of complete macroeconomic CGE models and to link these to several sectoral models.

Over the last decade, and with Brazil's 2008 publication of the National Plan on Climate Change (PNMC), research has been carried out to analyse mitigation measures and the socioeconomic impacts of climate policy - including carbon pricing - in Brazil. Some studies first explored detailed mitigation potentials with a range of sectoral models, to support ambitious decarbonisation targets, e.g., for the energy sector (Lucena et al., 2016) or in a cross-sectoral perspective (de Gouvello, 2010; Brasil, 2017). Other studies sought to assess the economic impacts of deforestation control - a central mitigation policy lever in Brazil - (Carvalho et al., 2017) and other land-use policies (da Silva et al., 2017; de Souza Ferreira Filho and Horridge, 2014; Ferreira Filho et al, 2015) by integrating regional CGE and land-use models. These studies provide key insights on land-use policies but do not connect to mitigation in other sectors (energy, transport, industry, etc.) to assess economy-wide climate policy.

On the other side of the spectrum, early analyses studied the economic impacts of carbon taxation in Brazil with static CGE models (Tourinho et al., 2003; Ferreira Filho and Rocha, 2008). More recently, carbon pricing policies were further explored with recursive, dynamic CGE models including some details on energy (Magalhães, 2013) and land-use sectors (Chen et al., 2013; Silva and Gurgel, 2012; Gurgel and Paltsev, 2014; Gurgel et al., 2019). In the latter case, modelling frameworks made it possible to connect deforestation control and land-use changes to mitigation in other sectors in long-run scenarios and to simulate economy-wide mitigation packages and carbon pricing to assess the macroeconomic implications of mitigation. The most recent contribution of this kind (Gurgel et al., 2019) explores the economic impacts of meeting the NDC target in Brazil with deforestation control and carbon pricing as part of a long-run analysis. However, these studies still build on a top-down vision of mitigation options within the standalone CGE modelling that has limited details at the sectoral scale and that do not explore in-depth the economic and social impacts of alternative carbon pricing schemes. Eventually, several studies analysed the distributional impacts of carbon pricing across different households groups (Magalhães, 2013; Winkler et al, 2017; da Silva Freitas et al., 2016; La Rovere et al, 2018b; Moz-Christofoletti and Pereda, 2021).

The present study is in line with the existing literature and aims to address the following research gaps: (i) account for more explicit and detailed mitigation measures across sectors as triggered by carbon pricing towards the 2030 NDC emissions target, clarifying the links between such mitigation and economy-wide impacts of carbon pricing, and (ii) explore alternative carbon pricing schemes compared to command-and-control and other policies, analysing their economic and distributional impacts in the NDC context. To address the first research gap and overcome the limits of using a standalone CGE model, we build on an integrated approach linking a set of sectoral models to CGE analysis; this follows 
research methodologies detailed in a few previous studies (La Rovere et al, 2018b; Brasil, 2017). Regarding the second research gap, we provide new policy insights on how to achieve economic and social goals through carbon pricing in the context of the 2030 NDC target in Brazil.

\section{Materials and Methods}

Our integrated modelling approach links a set of five sectoral models to one CGE model for Brazil. This section briefly describes these models, split into three energy demand models (transport; industry and buildings; and agriculture energy demand); a land-use model (BLUM) (which also determines the biofuel supply constraint); and an energy supply model (MATRIZ); as well as the CGE model. It also describes how these models are used to derive the simulated scenarios (including mitigation measures) and how they are effectively integrated into the assessment of these policy scenarios. A more detailed description of the models, including key features and underlying databases, can be found in the Supplementary Material (SM).

\subsection{Sectoral modelling}

The estimates for energy demand in this study are undertaken using sectoral bottom-up models, which apply or combine the above-described technical approaches. The models require similar inputs, such as demographic (population) and macroeconomic (GDP, sectoral GDP) data, as well as activity levels and energy intensity, to provide comparable outputs (e.g., final energy demand in tons of oil equivalent and GHG emissions). However, they may differ broadly in terms of sectoral specification, level of detail and data availability.

The 'Transport-Energy-Emissions Multi-Tier Analysis' (TEMA) model is used to calculate energy use in the Brazilian transport sector. The model was developed by Gonçalves et al. (2019) and applied in studies such as Goes et al. (2020a; 2020b) and Gonçalves et al. (2020). Energy-climate scenarios are designed by simulating the application of climate policies, market trends and user behaviour that best represent the transformations of society over the years. Macroeconomic data are used to project transport activity (and modal split) and the consequent use of energy and resulting carbon emissions. In TEMA, road transportation is the mode with the highest level of detail, considering 31 technologies that include vehicle categories (e.g., cars, buses, trucks) and powertrains (e.g., internal combustion engines, battery-powered electric vehicles, hybrid vehicles, etc.). The rail, air, water, and pipeline sectors are modelled in a more aggregate way, due to a lack of technology-level data. In their case, the 'Activity-Structure-Intensity-Fuel' (ASIF) approach is used to compute energy use and GHG emissions. 
The ASIF approach is also applied to estimate the energy consumption and GHG emissions of the Brazilian industrial sector disaggregated in eleven segments: (i) Iron and Steel, (ii) Iron alloys, (iii) Cement, (iv) Chemical industry, (v) Non-ferrous metals, (vi) Pulp and Paper, (vii) Food and Beverage, (viii) Textile, (ix) Mining and pelleting, (x) Ceramic, (xi) Other Industries. The estimation of GHG emissions is divided into two: (i) emissions from energy consumption and (ii) emissions from industrial processes and product use (IPPU). Overall, the industrial processes that emit GHG are the production of metals, cement and other mineral products, and chemical products. Product use emissions encompass $\mathrm{HFC}$ emissions for refrigeration and air conditioning and $\mathrm{SF}_{6}$ emissions from electricity transmission and distribution equipment.

GHG emissions from energy demand derived from buildings (residential, commercial and public administration) and agriculture are estimated considering historical trends in energy demand evolution and their continuity through 2030, according to different drivers. In the residential sector, energy demand responds to demographics and per capita income. In the services and agriculture sectors, demand is driven by sectoral GDP growth. In either of these sectors, no mitigation measure with significant abatement potential is triggered by pricing carbon below $10 \mathrm{USD} / \mathrm{tCO} 2 \mathrm{e}$. Given that no technological shifts are simulated, this computation is sufficiently detailed to provide the overall estimates of sectoral energy demand. Eventual differences across scenarios reflect only minor changes in per capita income and GDP share of agriculture and services.

The Brazilian Land Use Model (BLUM) is applied to estimate the GHG emissions from the Agriculture, Forestry, and Other Land Use sector (AFOLU). It plays a key role in determining the production levels of ethanol, biodiesel and homogeneous planted forests, which are demanded by other sectors. It also simulates the adoption of low carbon mitigation practices in agriculture as prescribed in the national Low Carbon Mitigation Plan - ABC Plan (pasture recovery, biological nitrogen fixation, forest-livestock integration systems and zero tillage). It has been applied in a variety of studies investigating the climate impacts of land use policies in Brazil (Moreira, 2016; Harfuch et al., 2017; Moreira et al., 2020). BLUM is a single-country, partial equilibrium, multisectoral and multiregional model. It represents the Brazilian agricultural sector through two modules: product supply-demand and land use. The model includes the following products: soybean, corn, cotton, rice, beans, wheat, barley, sugarcane, biodiesel, dairy, beef, pork, chicken and eggs. In terms of land use, these commodities can be broadly classified between agricultural land and pasture, while commercial forests are considered exogenous projections. These agricultural (and commercial forest) activities account for approximately $95 \%$ of the total Brazilian agricultural area. Like the deforestation rate, land set aside as conservation units and indigenous lands are determined exogenously. The amount of land earmarked for the restoration of native forests varies in the scenarios. In those with carbon pricing, the total area exceeds the level 
required for carbon offsetting. The surplus corresponds to the area already destined for forest restoration in the business-as-usual (BAU) scenario.

Finally, the MATRIZ model (CEPEL, 2020) is used to represent the Brazilian energy system and detail electricity supply and oil refining sectors. MATRIZ is a linear programming bottom-up model for medium- to long-term energy system planning, similar to MESSAGE and TIMES² (IEA-ETSAP, 2020; IIASA, 2020). Considering exogenous final energy demand and availability of resources, its objective function minimises the present value of the total cost of investment and system operation, choosing the best configuration in terms of capacity expansion and energy supply on the assessed horizon. Energy chains are represented by linking primary, secondary, final, and useful energy levels. A mix of different technologies represents energy conversions and resource extractions. To account for the Brazilian electricity sector complexity, four operating subsystems are considered. Besides, each period of the analysis is detailed into four seasons, each containing two energy demand levels: peak and nonpeak. Such a level of specification is essential for energy security by ensuring that the system meets seasonal and horo-seasonal demands and energy generation, as well as potential periods of critical hydrology. MATRIZ computes GHG emissions endogenously. A penalty is simulated in the objective function specifically for fossil fuel technologies to represent carbon pricing.

\subsection{The IMACLIM-BR model}

IMACLIM is an economy-wide multisectoral model designed to articulate with engineering representations of the energy system (Ghersi, 2015; Hourcade et al., 2006). ${ }^{3}$ For this study, the application of the open-economy version of IMACLIM to Brazil, IMACLIM-BR, evolved from a comparative statics model (Wills, 2013; Lefèvre et al., 2018) to a dynamic simulation model that pictures annual economic growth resulting from assumptions of labour endowment and productivity. The vector of domestic outputs at year $t, Y_{t}$, is a function of capital stock $K_{t}$, labour force $L_{t}$ and intermediate consumptions of energy and non-energy resources. Capital stock follows the standard accumulation $K_{t+1}=(1-\delta) K_{t}+I_{t}$ with constant depreciation $\delta$. Investment $I_{t}$ is the output used to build up $K$ at period $t$. Beyond these core specifications and to increase empirical relevance, similar

\footnotetext{
${ }^{2}$ MESSAGE and TIMES are both bottom-up, energy supply models that uses linear-programming to produce a least-cost energy system, optimized according to a number of user constraints, usually over medium to long-term time horizons.

${ }^{3}$ IMACLIM exists in a global multi-regional version (Crassous et al., 2006; Sassi et al., 2010) and in a growing number of country versions (Hourcade et al., 2010; Wills, 2013; Schers et al., 2015; Le Treut, 2017; De Lauretis, 2017; Gupta et al., 2019, 2020; Soummane et al., 2022; Le Treut et al., 2021). See http://www.centre-cired.fr/en/imaclim-network/imaclim-network-en/.
} 
to other country versions, IMACLIM-BR deviates from the neoclassical CGE standard through four salient features, thus creating a hybrid CGE model for Brazil. ${ }^{4}$

Firstly, IMACLIM-BR calibrates on original hybrid data reconciling national accounting statistics with energy balance and prices statistics. The recently updated 2015 data takes the form of a 19-sector Social Accounting Matrix backed by satellite accounts of six energy commodity flows consistent with documented agent-specific energy market prices. ${ }^{5}$ Hybrid accounting has a significant bearing on macroeconomic analysis through the reassessment of the cost shares of energy in production functions, through both the budget shares of energy for households and the breakdown of energy consumption across sectors and agents (Combet et al., 2014; Le Treut, 2017).

Secondly, IMACLIM-BR traces growth pathways under the constraint of energy flows at agent-specific prices and the capital requirements of energy supply and end-use (Ghersi, 2015). This allocates part of value-added to constrained energy expenses and part of primary factor endowments to constrained energy supply volumes. These constraints on volumes, costs, and prices weigh on economic growth.

Thirdly, IMACLIM-BR simulates suboptimal growth by building on exogenous investment pathways rather than intertemporal optimisation and by considering imperfect non-energy markets through underutilisation of both labour and capital. On the labour market, the inertia of real wages prevents full clearing, i.e., induces equilibrium unemployment specified through a 'wage curve' (Blanchflower and Oswald, 2005). The rate of capital utilisation is an exogenous variable effectively increasing the available capital stock. The trajectory of idle capacity mobilisation is calibrated as that compatible with the gradual reabsorption of unemployment under BAU conditions (for our BAU scenario, see below). It is common to all scenarios.

Lastly, IMACLIM-BR further deviates from the neoclassical paradigm by considering closure on foreign savings, i.e., the trade balance, to accommodate exogenous investment and households' savings dynamics and the public budget balance resulting from exogenous tax rates and public spending effort

\footnotetext{
${ }^{4}$ For the sake of transparency and to facilitate expansion to new economies, IMACLIM, including its Brazilian 'branch' IMACLIM-BR, is now open-access and hosted on Github (Le Treut et al., 2019). Additionally, Le Treut (2020) presents the generic equations of country versions of IMACLIM. All specifications therein apply to IMACLIM-BR unless specified otherwise in the following paragraphs.

${ }^{5}$ The 19 sectors are: Coal, Oil \& oil products excluding diesel, Natural gas, Biofuels, Diesel, Electricity, Forestry, Cattle, Other agriculture, Cement, Iron \& Steel, Non-ferrous metals, Chemicals, Dairy and meat products, Other food industries, Pulp and Paper, Other industries, Transports, Other activities. They are aggregated from the 40 -sector hybrid matrix published in Grottera et al. (2021).
} 
(as a share of GDP). This choice of closure is meant to represent monetary policy effectively tailoring foreign savings to bring total savings in line with investment requirements (Taylor and Lysy, 1979).

\subsection{Integrated modelling approach}

The coupling between the bottom-up models and IMACLIM-BR is carried out through the iterative exchange of key data, notably for sectoral economic activity, energy intensities and costs, traded energy and capital costs (Figure 1).

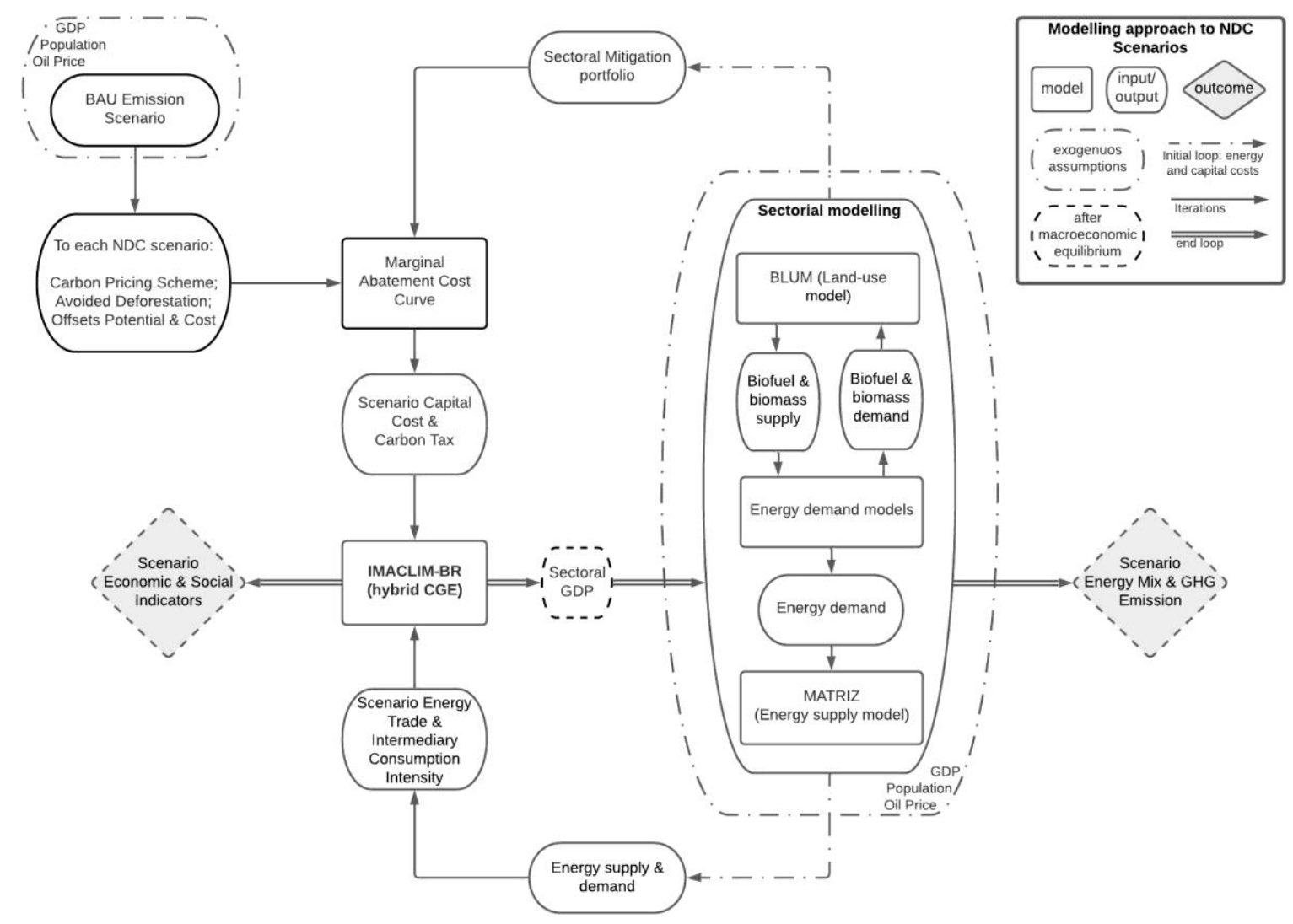

Figure 1 Integrated modelling diagram for Brazil's NDC scenarios

Source: the authors based on Wills (2013)

Each sectoral model estimates energy demand, considering the supply constraints for bioenergy given by the BLUM model. Based on total energy demand, the MATRIZ model computes total energy supply. The resulting energy scenario then informs IMACLIM-BR through trade and intermediate consumption intensities.

The availability of forest offsets was estimated exogenously as a cost supply curve (Waycarbon, 2019). These offsets were made available to other economic sectors as an option to meet mitigation targets with a limit of $20 \%$ of its emissions under the carbon pricing scheme in each year. This limit was 
proposed to ensure that decarbonization would be pursued in all economic sectors, and mainly to encourage low-carbon investments in industry.

The carbon price was increased until the NDC goal was reached, defining which mitigation measures should be simulated by sectoral models and total offsets used across the economy under each carbon pricing scenario. After that, sectoral models informed IMACLIM-BR about energy supply and demand, total required investments in mitigation and total offsets used as well as all related investments by sector for each scenario. This exchange of information allows mitigation costs and energy demand/supply to be estimated by sectoral models and to be consistent with capital demand and energy and technology coefficients in the CGE model. After ensuring macroeconomic equilibrium, in addition to economic and social indicators, IMACLIM-BR provides new activity levels by sector, starting again the iteration process to calculate the total energy demand and supply, the equilibrium price of carbon and the use of offsets. This iterative process between the CGE and the sectoral models continues until total emissions and activity levels converge to meet NDC targets.

\subsection{Scenario definition and assumptions}

Scenario assumptions were identified through a participatory process involving stakeholders from the Brazilian Forum on Climate Change. This Scenario Building Team (SBT) was made up of experts from the government, private sector, academia and civil society; it discussed and validated assumptions concerning market trends, performance of public policies and societal transformation, critically appraised to outline possible development pathways for the Brazilian economy. A more detailed description of such a process can be found in Goes et al. (2020a). Table 1 presents the main exogenous assumptions used in the simulation of scenarios.

From this process, the assumptions were then parameterised to quantify 24 mitigation options required to achieve Brazilian NDC targets, which are listed in the SM, along with their abatement potentials and average costs, following the approach proposed by de Gouvello et al. (2010). Implementation starts in 2021 and is assessed separately for the 2025 and 2030 NDC targets. The costs for a given mitigation option may vary widely between the two periods (2021-25 and 2026-30) due to increasing abatement potential over time and variations in costs assumptions (e.g., decreasing costs for electric vehicles and renewable electricity). In this exercise, deforestation rates are completely exogenous and are kept constant in all scenarios that meet NDC targets. The three scenarios are described next.

Reference Scenario (REF) - In this scenario, the mitigation measures outlined by the SBT are achieved through command-and-control measures, subsidies to investments and other policy instruments, and 
implemented by the federal government; no carbon pricing scheme is in force. Mitigation efforts are undertaken in land-use change and agriculture, industry, transportation and energy supply sectors. This scenario was created to serve as a basis for comparing its results with those scenarios obtained from the different carbon pricing schemes. In REF, as well as in all carbon pricing scenarios, the government actively reduces emissions to meet NDC targets, and deforestation rates are set exogenously to keep the constant level of $13,600 \mathrm{~km}^{2} /$ year throughout the period $2025-2030$ (including all biomes).

Emissions Pricing Scenario (EPS) - This is the basic emissions pricing scenario. A carbon tax is applied to all GHG from fossil fuel emissions and IPPU. The carbon tax triggers the adoption of mitigation measures to equate the marginal abatement cost across sectors so that the NDC targets are met. The carbon pricing scheme can be interpreted either as a carbon tax or an auction of carbon allowances. The climate policy is fiscally neutral, using carbon revenues to reduce labour taxes. This aims to decrease potential negative impacts of carbon taxation by favouring employment creation, increasing the Brazilian tax system's efficiency as a whole and thus enhancing national competitiveness, as advocated by Chen et al (2013). In this scenario, deforestation rates are set exogenously at the same levels as in REF to allow this exercise to focus on the effects of carbon pricing. An underlying assumption of EPS is that the carbon pricing structure provides the necessary conditions for offsets from the restoration of native vegetation and encourages these transactions, a condition that is not available in REF. The supply of such offsets are estimated at an average price of 6.3 USD/tCO2e and 8.4 USD/tCO2e for the 2021-25 and the 2026-30 periods, respectively. One of the most relevant outcomes in the carbon pricing scenarios is that the use of offsets at low costs limits the implementation of costlier measures in other sectors and lowers overall costs of mitigation. The abatement potential of offsets is estimated at 61 MtCO2e in 2025 and 122 MtCO2e in 2030 (details in WayCarbon, 2019). In REF, mitigation potential and costs by measure are estimated by the sectoral models and endorsed by the SBT. Additional investments to implement this set of mitigation measures are then enforced, by sector, in the CGE model as a shock, along with the new energy mix estimated by the MATRIZ model. In all scenarios under carbon pricing, all economic sectors are allowed to buy available offsets to replace costlier measures in other (non-land use) sectors.

Distributive Scenario (DS) - This scenario differs from EPS specifically regarding the recycling scheme of the carbon revenues. Instead of labour tax exemptions, carbon pricing revenues return to the economy in the form of direct transfers to the $20 \%$ lower-income households. This is an attempt to neutralise potential negative distributional impacts of carbon taxation (e.g., higher energy prices) on the most vulnerable, increasing the system's progressiveness and alleviating poverty. 


\begin{tabular}{|c|c|c|c|}
\hline & REF & EPS & DS \\
\hline World population in 2030 & \multicolumn{3}{|c|}{8.3 billion } \\
\hline \multirow{2}{*}{$\begin{array}{l}\text { Global average annual } \\
\text { economic growth rate }\end{array}$} & \multicolumn{3}{|c|}{ 2015-2020: 3.8\% } \\
\hline & \multicolumn{3}{|c|}{ 2021-2030: 3.2\% } \\
\hline Brazilian population in 2030 & \multicolumn{3}{|c|}{225 million } \\
\hline \multirow{5}{*}{$\begin{array}{l}\text { Domestic average annual } \\
\text { economic growth rate }\end{array}$} & \multicolumn{3}{|c|}{ 2015: $-3.8 \%$} \\
\hline & \multicolumn{3}{|c|}{ 2016: $-3.6 \%$} \\
\hline & \multicolumn{3}{|c|}{ 2017: $-1.0 \%$} \\
\hline & \multicolumn{3}{|c|}{ 2018-2020: $2.5 \%$} \\
\hline & \multicolumn{3}{|c|}{ 2021-2030: 3.2\% } \\
\hline International oil price in 2030 & \multicolumn{3}{|c|}{$\begin{array}{l}83 \text { USD/bbl. (constant prices of 2015). } \\
\text { The pathway is consistent with the IEA low-oil price scenario. }\end{array}$} \\
\hline \multicolumn{4}{|l|}{$\begin{array}{l}\text { Deforestation rates }\left(\mathrm{km}^{2} \text { per }\right. \\
\text { year - all biomes) (offsets are } \\
\text { accounted separately) }\end{array}$} \\
\hline Year 2025 & \multicolumn{3}{|c|}{13,600} \\
\hline Year 2030 & \multicolumn{3}{|c|}{13,600} \\
\hline NDC targets & $\checkmark$ & $\checkmark$ & $\checkmark$ \\
\hline Carbon pricing mechanism & & $\checkmark$ & $\checkmark$ \\
\hline $\begin{array}{l}\text { Offsets from native forest } \\
\text { restoration allowed on the } \\
\text { scenario }\end{array}$ & & $\checkmark$ & $\checkmark$ \\
\hline
\end{tabular}

Table 1 Exogenous assumptions of scenarios, NDC targets and emissions pricing schemes

Source: IBGE (2020), BACEN (2018), Energy Research Office (EPE, 2014), IEA (IEA, 2019) and expert elicitation

\section{Results}

In REF, all mitigation measures proposed by the SBT to meet the NDC are implemented. They are listed in the SM, alongside their assumed abatement potential and costs for periods 2021-2025 and 20262030 (as carbon pricing is implemented from 2021 until 2030). Offsets from native vegetation are not available in REF, as explained in Section 3.3, since no emissions pricing scheme that would allow compensation between sectors is in operation. As stated before, an underlying assumption of EPS and DS is that the carbon pricing structure provides the necessary conditions for offsets from the

\footnotetext{
${ }^{6}$ These are the growth rates for the BAU scenario (for details on this scenario please take a look at the SM). The introduction of mitigation measures and emissions pricing schemes are simulated over the BAU scenario and affect final GDP levels of REF, EPS and DS.
} 
restoration of native vegetation and encourages these transactions, a condition that is not available in REF.

In scenarios with carbon pricing mechanisms (EPS and DS), measures are ranked by ascending abatement cost so that the cheapest options are implemented first until the required emissions reduction is reached. We highlight the equalisation of the carbon value between emissions pricing scenarios, which is a surprising result. This is due to the remarkable flexibility in the use of offset, coupled with the large supply of native forest offsets available at a relatively stable cost (the offsets supply curve is pretty flat at that level of high demand), which ended up being the marginal mitigation option (the carbon price threshold) in all scenarios (please refer to the SM for detailed mitigation potential and costs rank). The impact of the different carbon pricing schemes on activity levels and emissions was only marginal. The additional amount of offsets needed to compensate for these marginal cost variations is quite small if compared to the total offsets supply curve and didn't lead to significant price variations at that level. By construction, offsets were limited to $20 \%$ of total emissions under the carbon pricing scheme for each year, but in practice, they reached only $16 \%$ of emissions under the carbon pricing scheme in 2030 and less than 7\% of total emissions for both EPS and DS in 2030.

A significant share of measures can be implemented at negative costs. This is valid for most energy efficiency measures and for heat recovery in industrial sectors. Mode shifts in the transport sector (e.g., from roads to railways and waterways) and other efficiency measures can also be implemented at negative costs. Barriers such as high upfront costs and higher risks are usually mentioned to explain why those mitigation measures were not implemented before.

In REF, without carbon pricing, many mitigation measures were included in the sectoral models to promote emission reductions. In the carbon pricing scenarios (EPS, DS), only measures that cost less than the price of carbon were included, reducing the overall cost of the economy to meet the NDC targets $^{7}$. As a result, energy-related emissions in EPS and DS are about 12\% higher than in REF; thus, mitigation of energy-related emissions contributes less to overall mitigation effort under the carbon pricing scenarios than REF as the emissions reductions of some of the costlier energy-related measures were substituted by offsets. As mentioned before, this is one of the reasons why offsets use was limited - to ensure that decarbonization would be pursued in all economic sectors.

Table 2 compares the results of the carbon pricing scenarios and REF. In 2030, GDP reaches 2.67 trillion USD in REF compared to 2.73 trillion USD in the carbon pricing scenarios (+2.2\%). The carbon pricing

\footnotetext{
${ }^{7}$ The set of mitigation measures implemented on each scenario is available in the SM.
} 
scheme stimulates the use of offsets, which replace mitigation measures with marginal abatement cost above 8.4 USD/tCO2e; this is because the offsets supply at that cost is big enough to play an important role (WayCarbon, 2019). The use of offsets is allowed for all economic sectors but limited to $20 \%$ of emissions under the carbon pricing scheme. Thus, the use of offsets reduces the overall costs of mitigation, partly attenuates the recessive effect of the carbon price, and, therefore, helps drive a higher level of economic performance, as measured by GDP. For the specific set of mitigation options implemented under each scenario, please refer to the SM.

Among the carbon pricing scenarios, EPS achieves a higher level of GDP per capita, albeit marginally, despite presenting a lower average income for the poorest segment of the population. Carbon pricing revenues are about the same in both carbon pricing scenarios.

The carbon pricing schemes also lead to higher price indices, which contributes to deteriorating terms of trade and has major implications for trade balance results. The trade balance falls in relation to REF, even though figures are better than in the base year.

Carbon pricing scenarios allow for significant savings in terms of mitigation investments, and by optimising the order of the implemented mitigation options, as stated before. In addition, carbon pricing serves as a long-term signal to economic sectors, stating that a long-term net-zero goal should be pursued. In both carbon pricing scenarios, the recycling scheme for revenues allows meeting other specific objectives: support employment or alleviate poverty/inequalities. These policies lead to a more efficient economy, resulting in higher GDP and employment, compared to REF. As a result, unemployment rates are significantly lower in both of the carbon pricing scenarios (6.3\%) than in REF (7.6\%). The use of carbon revenues to reduce taxes on labour decreases distortions in the economy and is key to the creation of approximately 1.5 million jobs compared to REF. Those jobs are created mainly in the services and light industry sectors. The carbon price penalises a higher proportion of carbon-intensive sectors in both scenarios, and recycling carbon revenues favours either more labourintensive sectors (EPS) or poorer household classes (DS). 


\begin{tabular}{|c|c|c|c|c|c|}
\hline Year/Scenario & 2015 & 2020 & $\begin{array}{r}\text { REF } \\
(2030)\end{array}$ & $\begin{array}{r}\text { EPS } \\
(2030)\end{array}$ & $\begin{array}{r}\text { DS } \\
(2030)\end{array}$ \\
\hline GDP (Billion 2015 USD) & 1,896 & 1.908 & 2,670 & 2,729 & 2,729 \\
\hline GDP variation in relation to $\mathrm{REF}$ & - & - & - & $+2.23 \%$ & $+2.21 \%$ \\
\hline GDP per capita (Thousand 2015 USD) & 9.37 & 8.95 & 11.87 & 12.13 & 12.13 \\
\hline Trade Balance (\% of GDP) & $-0.40 \%$ & -0.38 & $3.10 \%$ & $1.80 \%$ & $1.70 \%$ \\
\hline Unemployment rate & $9.50 \%$ & $8.45 \%$ & $7.56 \%$ & $6.29 \%$ & $6.33 \%$ \\
\hline Price index in relation to $\mathrm{REF}(\mathrm{REF}=1)$ & - & - & 1.00 & 1.04 & 1.05 \\
\hline Total net emissions (GtCO2e) & 1.6 & 1.5 & 1.2 & 1.2 & 1.2 \\
\hline 2030 carbon price (2015 USD/tCO2e) & - & - & - & 8.4 & 8.4 \\
\hline $\begin{array}{l}\text { Carbon pricing revenues (2021-2030) (Billion } \\
2015 \text { USD) }\end{array}$ & - & - & - & 24.4 & 24.4 \\
\hline Offsets (MtCO2e) & - & - & - & 83 & 83 \\
\hline 2030 offsets revenues (Billion 2015 USD) & - & - & - & 0.70 & 0.70 \\
\hline $\begin{array}{l}\text { CAPEX in mitigation (2021-2030) (Billion } 2015 \\
\text { USD) }\end{array}$ & - & - & 63.2 & 31.3 & 31.3 \\
\hline $\begin{array}{l}\text { Avoided CAPEX in relation to REF (2021-2030) } \\
\text { (Billion } 2015 \text { USD) }\end{array}$ & - & - & - & 31.9 & 31.9 \\
\hline
\end{tabular}

\section{Table 2 Main macroeconomic results of EPS and DS in comparison to REF} Source: The authors' IMACLIM-BR simulations.

The carbon revenues used to cut labour taxes explains lower unemployment in EPS compared to DS. In DS, carbon revenues are distributed to the $20 \%$ poorest households ( $\mathrm{HH} 1)$. Therefore, the possibilities to attenuate negative employment impacts are more limited, leading to higher unemployment. Table 3 compares the results of the carbon pricing scenarios and REF, presenting income, inequality and employment indicators. 


\begin{tabular}{|c|c|c|c|c|c|}
\hline Demography assumptions & 2015 & 2020 & 2030 & & \\
\hline Population (million) & 204.9 & 213.2 & 226.4 & & \\
\hline HH1 (poorest $20 \%$ of households) & 48.6 & 50.5 & 53.7 & & \\
\hline $\mathrm{HH} 2$ ( $40 \%$ of households) & 80.7 & 84.0 & 89.2 & & \\
\hline HH3 ( $30 \%$ of households) & 58.0 & 60.3 & 64.1 & & \\
\hline $\mathrm{HH} 4$ (richest $10 \%$ of households) & 17.6 & 18.3 & 19.5 & & \\
\hline Income, inequality and employment results & 2015 & 2020 & REF & EPS & DS \\
\hline \multicolumn{6}{|l|}{ Real disposable income per capita (USD 2015) } \\
\hline $\mathrm{HH} 1$ & 1,149 & 1,169 & 1,880 & 2,155 & 2,224 \\
\hline $\mathrm{HH} 2$ & 3,303 & 5,256 & 4,592 & 4,944 & 4,931 \\
\hline HH3 & 8,383 & 11,154 & 10,512 & 10,893 & 10,877 \\
\hline $\mathrm{HH} 4$ & 32,272 & 38,176 & 37,784 & 38,166 & 38,121 \\
\hline Ratio of disposable income per capita HH4/HH1 & 28.09 & 26.51 & 20.10 & 17.71 & 17.14 \\
\hline \multicolumn{6}{|l|}{ Purchasing power $(2015=1)$} \\
\hline HH1 & 1 & 1.02 & 1.64 & 1.88 & 1.94 \\
\hline $\mathrm{HH} 2$ & 1 & 1.00 & 1.39 & 1.50 & 1.49 \\
\hline HH3 & 1 & 0.98 & 1.25 & 1.30 & 1.30 \\
\hline $\mathrm{HH} 4$ & 1 & 0.96 & 1.17 & 1.18 & 1.18 \\
\hline Jobs - Total (thousand FTE) & 101,945 & 107,041 & 111,628 & 113,166 & 113,119 \\
\hline Jobs - Energy sector & 550 & 587 & 610 & 616 & 616 \\
\hline Jobs - Agriculture and Livestock & 26,674 & 28,489 & 27,211 & 27,111 & 27,094 \\
\hline Jobs - Industry & 22,219 & 23,879 & 24,675 & 24,938 & 24,923 \\
\hline Jobs - Services & 52,502 & 54,087 & 59,132 & 60,501 & 60,486 \\
\hline Gini coefficient & 0.51 & 0.51 & 0.473 & 0.458 & 0.456 \\
\hline Average real wage $(2015=1)$ & 1 & 1.10 & 1.04 & 1.08 & 1.08 \\
\hline
\end{tabular}

FTE: Full-time equivalents, corresponding to 44 weekly hours

\section{Table 3 Demography and socioeconomic results of EPS and DS in comparison to REF Source: The authors' IMACLIM-BR simulations.}

Employment levels are closely related to household income. Higher employment and wage levels in our carbon pricing scenarios directly impact households' income levels, particularly those of $\mathrm{HH} 1$ and $\mathrm{HH} 2$ groups (bottom $60 \%$ household income levels), which depend more on labour income (Grottera 
et al., 2020). The DS scenario specifically benefits HH1 (the $20 \%$ poorest households, the majority of which are under the extreme poverty line in the base year), because it directly transfers collected carbon revenues to them.

Although DS is not the scenario with the highest levels of economic activity, it mitigates adverse impacts of carbon taxation on poor households. Even in EPS, income gains are significant compared to REF, thanks to higher levels of economic activity, lower labour charges and more and better employment opportunities reflected in more jobs, higher average wage and income. EPS and DS also prove to be progressive in terms of income distribution; in 2030, the Gini coefficient is lower in both of these scenarios than in REF. The ratio between the disposable income per capita of $\mathrm{HH} 4$ and $\mathrm{HH} 1$ (10\% richest vs. $20 \%$ poorest) provides another useful metric; this ratio decreases in the carbon pricing scenarios, particularly in DS. Thus, from a distributional impact perspective, the carbon pricing policy scenarios are both beneficial compared to REF.

The aggregate price of the consumption basket varies according to the expenditure profile of the different household groups, where we compute a specific relative Fisher price index for each group ${ }^{8}$. By deflating the disposable income per capita with those indices, we derive the evolution of households' purchasing power. Carbon pricing scenarios presents higher purchasing power for households, particularly for lower-income households ( $\mathrm{HH} 1$ and $\mathrm{HH} 2$ ), for which real income gains are significant, as explained above. We highlight the substantial increase in HH1's purchasing power in DS, in which carbon revenues are directly transferred to them.

\section{Discussion}

Carbon pricing policy scenarios show higher rates of economic growth than REF up to 2030. The fiscal neutrality assumption and the use of carbon pricing revenues to reduce distortionary taxes, such as labour taxes, also make it possible to increase the real disposable income of all income classes due to the greater number of jobs created in the economy.

The carbon pricing schemes encourage the use of offsets from native vegetation restoration by productive sectors and has an important impact on the socio-economic and mitigation results of the study. At a cost just below 10 USD/tCO2e up to 2030, offsets end up being the marginal mitigation measure in all carbon pricing scenarios, thus equating marginal abatement costs among sectors at this

\footnotetext{
${ }^{8}$ All price variations are relative to the numéraire of the model, that is, the imported composite good. More details can be found in Le Treut (2020).
} 
level. While the costs of offsets will increase progressively, other studies (La Rovere et al, 2018a; La Rovere et al, 2018b;) have shown that they will remain a key asset and option to allow Brazil to follow a deep decarbonisation pathway up to 2050 and to achieve the recently announced indicative target of climate neutrality in 2060 (Brazil, 2020).

This comparative analysis of the results from carbon pricing schemes coupled with different approaches to proper recycling of revenues back to the economy (ensuring fiscal neutrality) illustrate how such revenue recycling can address different types of socioeconomic goals: EPS improves GDP levels compared to the REF scenario; using carbon revenues to reduce labour taxes can foster employment generation; DS protects low-income households from price increases and improves income distribution; using carbon revenues to increase social transfers to poor households can provide fair compensation to them (alleviating poverty and inequality).

These results are in line with Moz-Christofoletti and Pereda (2021), who found that a social tariff to the poorest households, financed by a carbon tax, could reduce the regressive-ness of a carbon tax. Diniz Oliveira et al (2019), also conclude that despite small distributive effects in terms of household consumption, it is important to reduce negative impacts from the climate policy, particularly to diminish potential distributional effects. The results confirm that such compensation mechanisms are critical when designing and implementing carbon tax policy.

\section{Conclusion}

This study simulated scenarios with carbon pricing policies implemented under different conditions to meet the 2030 NDC targets in Brazil. It assessed the relative cost-effectiveness and socioeconomic performance of carbon pricing policies compared to alternatives (REF). A key finding of this research is that a relatively low carbon price (less than 10 USD/tCO2e) is required to meet Brazilian NDC targets up to 2030. This is due in large part to the country's huge mitigation potential at low costs (La Rovere et al, 2018b) and the large supply of offsets that are available from forest offsets (WayCarbon, 2019). A $20 \%$ limit of its contribution to meet industry emissions caps allows ensuring that the energy transition is not too delayed by this potential.

Results of this research confirm that the flexibility enabled by carbon pricing makes it a more costeffective policy tool to achieve both NDC targets and other development goals compared to alternative policies (command-and-control, subsidies to investments and other policy instruments alone). The carbon pricing policy scenarios take advantage of the use of forest offsets to lower the total economic 
cost of mitigation, where avoided investment in costly mitigation measures is on the order of 32 billion USD from 2021 to 2030.

Carbon pricing schemes may also help ensure a smooth transition to a low carbon society in Brazil. If carbon pricing is introduced, it will be important to promote regular adjustments on the carbon price signal to meet Brazilian mitigation targets in the medium- to long term, to further advance a clean energy mix and build on the great potential of offsets from AFOLU; it will also be important to address the urgent priorities for economic development, including a steady reduction of economic inequalities in the country.

Political acceptance of new policy is key. This was recently illustrated by the 'yellow vest' movement in France and the general strike led by truck drivers in Brazil. These social movements and events show the importance of political acceptability and how this will hinge on the balance achieved across mitigation and development goals. In the real world, the political economy of the carbon pricing agenda will probably require a mixed approach between the two contrasted scenarios here, sharing the allocation of carbon pricing revenues between the goals of employment generation and of compensating the negative impacts on the purchasing power of low-income households. . These social upheavals and political crises point to a conclusion from the Stiglitz-Stern Commission (2017) about the essential role of complementary policies to ensure the success of any carbon pricing scheme. 


\section{References}

Alton, T., Arndt, C., Davies, R., Hartley, F., Makrelov, K., Thurlow, J., Ubogu, D., 2014. Introducing carbon taxes in South Africa. Appl. Energy 116, 344-354.

Arndt, C., Davies, R., Gabriel, S., Makrelov, K., Merven, B., Hartley, F., Thurlow, J., 2016. A sequential approach to integrated energy modeling in South Africa. Appl. Energy 161, 591-599.

BCB BACEN (2018) Relatório de Inflação. Banco Central do Brasil. S - setembro de 2018. Brasília.

Blanchflower, D. G., Oswald, A. J. (2005). "The wage curve reloaded". National Bureau of Economic Research no. w11338. Available at https://www.nber.org/papers/w11338.pdf.

Böhringer, C., 1998. The synthesis of bottom-up and top-down in energy policy modeling. Energy Econ. 20, 233-248.

Böhringer, C., Bye, B., Faehn, T., Rosendahl, K.E., 2017. Output-based rebating of carbon taxes in a neighbour's backyard: Competitiveness, leakage and welfare. Can. J. Econ. 50, 426-455.

Böhringer, C., Rutherford, T.F., 1997. Carbon taxes with exemptions in an open economy: a general equilibrium analysis of the German tax initiative. J. Environ. Econ. Manag. 32, 189-203.

Böhringer, C., Rutherford, T.F., 2008. Combining bottom-up and top-down. Energy Econ. 30, 574-596.

Boyce, J.K., 2018. Carbon pricing: effectiveness and equity. Ecol. Econ. 150, 52-61.

Brasil, 2016. Intended nationally determined contribution towards achieving the objective of the United Nations Framework Convention On Climate Change. Available at: https://www4.unfccc.int/sites/ndcstaging/PublishedDocuments/Brazil\%20First/BRAZIL\%20iNDC\%20english \%20FINAL.pdf

Brasil, 2017. Modelagem integrada e impactos econômicos de opções setoriais de baixo carbono / organizador Régis Rathmann. - Brasília: Ministério da Ciência, Tecnologia, Inovações e Comunicações, ONU Meio Ambiente, 2017.

Brasil, 2020. Brazil's Nationally Determined Contribution (NDC). Available at:

https://www4.unfccc.int/sites/ndcstaging/PublishedDocuments/Brazil\%20First/Brazil\%20First\%20NDC\%20( Updated\%20submission).pdf

Carvalho, T.S., Domingues, E.P., Horridge, J.M., 2017. Controlling deforestation in the Brazilian Amazon: Regional economic impacts and land-use change. Land Use Policy 64, 327-341. 
CAT, 2021. Carbon Action Tracker. New Climate Institute and Climate Analytics. Available at: https://climateactiontracker.org/countries/brazil/\#

Cepel (2020) 'MATRIZ - Energy Matrix Projection Model'. Available at: http://www.cepel.br/en_us/products/computer-programs-by-category/menu/matriz-energy-matrixprojection-model-2.htm (Accessed: 11 November 2020).

Chen, Y.-H.H., Timilsina, G.R., Landis, F., 2013. Economic implications of reducing carbon emissions from energy use and industrial processes in Brazil. J. Environ. Manage. 130, 436-446.

Combet, E., Ghersi, F., Lefèvre, J., Le Treut, G. (2014). Construction of hybrid Input-Output tables for E3 CGE model calibration and consequences on energy policy analysis. GTAP resource \#4524, Global Trade Analysis Program, Purdue University, $27 \mathrm{p}$.

Crassous, R., Hourcade, J.C., Sassi, O., (2006). “Endogenous Structural Change and Climate Targets. Modeling experiments with IMACLIM-R." In Edenhofer O., Carraro C., Kohler J. and Grubb M., eds., Endogenous Technological Change and the Economics of Atmospheric Stabilisation. The Energy Journal, Special Issue: 259276.

da Silva Freitas, L.F., de Santana Ribeiro, L.C., de Souza, K.B., Hewings, G.J.D., 2016. The distributional effects of emissions taxation in Brazil and their implications for climate policy. Energy Econ. 59, 37-44.

da Silva, J.G., Ruviaro, C.F., de Souza Ferreira Filho, J.B.S., 2017. Livestock intensification as a climate policy: Lessons from the Brazilian case. Land Use Policy 62, 232-245.

Dai, H., Xie, X., Xie, Y., Liu, J., Masui, T., 2016. Green growth: The economic impacts of large-scale renewable energy development in China. Appl. Energy 162, 435-449.

de Gouvello, C., 2010. Brazil Low-carbon Country Case Study.

De Lauretis, S. (2017). Modélisation des impacts énergie/carbone de changements de modes de vie. Une prospective macro-micro fondée sur les emplois du temps. Economies et finances. Université Paris-Saclay, 2017. In French. Available at: https://tel.archives-ouvertes.fr/tel-01746139.

Diniz Oliveira, T., Gurgel, A.C., Tonry, S., 2019. International market mechanisms under the Paris Agreement: A cooperation between Brazil and Europe. Energy Policy 129, 397-409.

Drouet, L., Haurie, A., Labriet, M., Thalmann, P., Vielle, M., Viguier, L., 2005. A coupled bottom-up/top-down model for GHG abatement scenarios in the Swiss housing sector, in: Energy and Environment. Springer, pp. 27-61.

EPE (2014) ‘Plano Nacional de Energia 2050 - Cenário econômico’. Rio de Janeiro. 
Ferreira Filho, J.B.S., Horridge, M., 2014. Ethanol expansion and indirect land use change in Brazil. Land Use Policy 36, 595-604.

Bento de Souza Ferreira Filho, J.B.S., Ribera, L., Horridge, M., 2015. Deforestation control and agricultural supply in Brazil. Am. J. Agric. Econ. 97, 589-601.

Filho, J.B. de S.F., Rocha, M.T., 2008. Economic evaluation of public policies aiming the reduction of greenhouse gas emissions in Brazil. J. Econ. Integr. 709-733.

Freire-González, J., 2018. Environmental taxation and the double dividend hypothesis in CGE modelling literature: A critical review. J. Policy Model. 40, 194-223.

Frey, M., 2017. Assessing the impact of a carbon tax in Ukraine. Clim. Policy 17, 378-396.

Fujimori, S., Oshiro, K., Shiraki, H., Hasegawa, T., 2019. Energy transformation cost for the Japanese midcentury strategy. Nat. Commun. 10, 1-11.

Ghersi, F.,2015. Hybrid Bottom-up/Top-down Energy and Economy Outlooks: A Review of IMACLIM-S Experiments. Frontiers in Environmental Science 3 (74), 1-18. https://doi.org/10.3389/fenvs.2015.00074.

Ghersi, F., \& Hourcade, J. C.,2006. Macroeconomic consistency issues in E3 modeling: the continued fable of the elephant and the rabbit. The Energy Journal Special Issue on Hybrid Modeling, 39-61. DOI 10.5547/ISSN0195-6574-EJ-VoISI2006-NoSI2-3.

Goes, G. V., Gonçalves, D. N. S., D’Agosto, M. de A., Bandeira, R. A. de M., et al., 2020. Transport-energyenvironment modeling and investment requirements from Brazilian commitments. Renewable Energy, 157, 303-311. doi: 10.1016/j.renene.2020.05.032.

Goes, G. V., Gonçalves, D. N. S., D'Agosto, M. de A., La Rovere, E. L., et al., 2020. MRV framework and prospective scenarios to monitor and ratchet up Brazilian transport mitigation targets. Climatic Change, 162(4), 2197-2217. doi: 10.1007/s10584-020-02767-6.

Gonçalves, D. N. S. et al. (2019). Energy use and emissions scenarios for transport to gauge progress toward national commitments. Energy Policy, 135, 110997. doi: 10.1016/j.enpol.2019.110997.

Gonçalves, D. N. S., Goes, G. V. and D'Agosto, M. A., 2020. Energy Transition to Brazil: Paris Agreement Compatible Scenario for the Transport sector up to 2050. Available at: www.climate-transparency.org.

Goulder, L.H., 2013. Climate change policy's interactions with the tax system. Energy Econ. 40, S3-S11.

Grottera, C., Ferrazzo Naspolini, G., Le Treut, G., Wills, W., Laurent, M., 2021. Hybrid Input-Output tables for Brazil at year 2015. Mendeley Data, V1, doi: 10.17632/hpksctgb6b.1 
Grottera, C., La Rovere, E.L., Wills, W., Pereira Jr, A.O., 2020. The role of lifestyle changes in low-emissions development strategies: an economy-wide assessment for Brazil. Climate Policy 20(2), 217-233.

Gupta, D., Ghersi, F., Vishwanathan, S. S., \& Garg, A., 2019. Achieving sustainable development in India along low carbon pathways: Macroeconomic assessment. World Development, 123, 104623.

https://doi.org/10.1016/j.worlddev.2019.104623.

Gupta, D., Ghersi, F., Vishwanathan, S. S., \& Garg, A., 2020. Macroeconomic assessment of India's development and mitigation pathways. Climate Policy 20 (7), 779-799.

https://doi.org/10.1080/14693062.2019.1648235

Gurgel, A.C., Paltsev, S., 2014. Costs of reducing GHG emissions in Brazil. Clim. Policy 14, 209-223.

Gurgel, A.C., Paltsev, S., Breviglieri, G.V., 2019. The impacts of the Brazilian NDC and their contribution to the Paris agreement on climate change. Environ. Dev. Econ. 24, 395-412.

Harfuch, L., Bachion, L. C., Moreira, M. M. R., Nassar, A. M. \& Carriquiry, M., 2017. 'Empirical Findings from Agricultural Expansion and Land Use Change in Brazil', in Handbook of Bioenergy and Policy 2. Springer, pp. 273-302.

Hourcade, J. C., Jaccard, M., Bataille, C., Ghersi, F., 2006. Hybrid Modeling: New Answers to Old Challenges". Introduction to the The Energy Journal Special Issue on Hybrid Modeling, 1-11. Accessible at: https://www.jstor.org/stable/23297043.

Hourcade, J.-C., Ghersi F., Combet, E., Thery D., 2010. Carbon Tax and Equity: The Importance of Policy Design. In Dias Soares, C., Milne, J., Ashiabor, H., Deketelaere, K., Kreiser, L. (ed.), Critical Issues in Environmental Taxation, Oxford University Press, Oxford, pp. 277-295.

Hourcade, J.C., Jaccard, M., Bataille, C., Ghersi, F., 2006. Hybrid modeling: New answers to old challenges. Energy J. 2, 1-12.

IBGE, 2020. Estimativas da população residente para os municípios e para as unidades da federação brasileiros com data de referência em 10 de julho de 2020 : [notas metodológicas]. Available at: https://sidra.ibge.gov.br/tabela/6579\#resultado (Accessed: 7 December 2020).

IEA, 2019. Global EV Outlook 2018World Energy Outlook 2019 International Energy Agency. Paris. Towards cross-modal electrification. Internationa Energy Agency. Available at: www.iea.org/t\&c/.

IEA-ETSAP, 2020. IEA-ETSAP | Times. Available at: https://iea-etsap.org/index.php/etsap-tools/modelgenerators/times (Accessed: 11 November 2020). 
IIASA, 2020. MESSAGE - IIASA. Available at:

https://iiasa.ac.at/web/home/research/researchPrograms/Energy/MESSAGE.en.html（Accessed: November 2020).

INESC, 2020. Instituto de Estudos Socioeconômicos. Subsídios aos Combustíveis Fósseis no Brasil. Brasília, Outubro, $42 \mathrm{p}$.

INPE, 2021. Monitoramento do Desmataemnto da Floresta Amazônica Brazileira por Satélite. Instituto Nacional de Pesquisas Espaciais. Available at:

http://www.obt.inpe.br/OBT/assuntos/programas/amazonia/prodes

Karapinar, B., Dudu, H., Geyik, O., Yakut, A.M., 2019. How to reach an elusive INDC target: macro-economic implications of carbon taxation and emissions trading in Turkey. Clim. Policy 19, 1157-1172.

Krook-Riekkola, A., Berg, C., Ahlgren, E.O., Söderholm, P., 2017. Challenges in top-down and bottom-up softlinking: Lessons from linking a Swedish energy system model with a CGE model. Energy 141, 803-817.

La Rovere, E.L., Grottera, C., Wills, W., 2018a. Overcoming the financial barrier to a low emission development strategy in Brazil. International Economics 155, 61-68.

La Rovere, E.L., Wills, W., Grottera, C., Dubeux, C.B.S., Gesteira, C. 2018b. Economic and social implications of low-emission development pathways in Brazil. Carbon Management 9(5), 563-574.

Lanz, B., Rausch, S., 2011. General equilibrium, electricity generation technologies and the cost of carbon abatement: A structural sensitivity analysis. Energy Econ. 33, 1035-1047.

Le Treut, G., (2017). Methodological proposals for hybrid modelling: consequences for climate policy analysis in an open economy (France). PhD thesis, Université Paris-Est, Paris. Available at https://hal.archivesouvertes.fr/tel-01707559/document .

Le Treut, G., 2020. Description of the IMACLIM-Country model: A country-scale computable general equilibrium model to assess macroeconomic impacts of climate policies. Available at https://hal.archivesouvertes.fr/view/index/identifiant/hal-02949396.

Le Treut, G., Combet, E., Lefèvre, J., Teixeira, A., Baudin, A., 2019. IMACLIM-Country platform: a country-scale computable general equilibrium model. URL: https://zenodo.org/record/3403961, doi:10.5281/ZENODO.3403961.

Le Treut, G., Lefèvre, J., Lallana, F., Bravo, G., 2021. The multi-level economic impacts of deep decarbonization strategies for the energy system. Energy Policy, under revision. 
Lefèvre, J., Wills, W., Hourcade, J-C., 2018. Combining low-carbon economic development and oil exploration in Brazil? An energy-economy assessment, Climate Policy 18:10, 1286-1295.

DOI 10.1080/14693062.2018.1431198

Liang, Q.-M., Wang, T., Xue, M.-M., 2016. Addressing the competitiveness effects of taxing carbon in China: domestic tax cuts versus border tax adjustments. J. Clean. Prod. 112, 1568-1581.

Lu, C., Tong, Q., Liu, X., 2010. The impacts of carbon tax and complementary policies on Chinese economy. Energy Policy 38, 7278-7285.

Lucena, A.F., Clarke, L., Schaeffer, R., Szklo, A., Rochedo, P.R., Nogueira, L.P., Daenzer, K., Gurgel, A., Kitous, A., Kober, T., 2016. Climate policy scenarios in Brazil: A multi-model comparison for energy. Energy Econ. 56, 564-574.

Magalhães, A.S., 2013. Economia de baixo carbono no Brasil: alternativas de políticas e custos de redução de emissões de gases de efeito estufa. Tese de Doutorado. UFMG. Available at:

https://repositorio.ufmg.br/handle/1843/AMSA-9GXQ2U

Mataveli, G.A.V., Chaves, M.E.D., Brunsell, N.A., Aragão, L.E.O.C., 2021. The emergence of a new deforestation hotspot in Amazonia. Perspectives in Ecology and Conservation 19 (1), 33-36.

Mattoo, A., Subramanian, A., van der Mensbrugghe, D., He, J., 2013. Trade effects of alternative carbon border-tax schemes. Rev. World Econ. 149, 587-609.

McKitrick, R., 1997. Double dividend environmental taxation and Canadian carbon emissions control. Can. Public Policy 417-434.

Meng, S., Siriwardana, M., McNeill, J., 2013. The environmental and economic impact of the carbon tax in Australia. Environ. Resour. Econ. 54, 313-332.

Moreira, M. M. R. (2016) Estratégias para Expansão do Setor Sucroenergético e suas Contribuições para a NDC Brasileira. Universidade de Campinas. Available at:

http://repositorio.unicamp.br/bitstream/REPOSIP/330246/1/Moreira_MarceloMeloRamalho_D.pdf.

Moreira, M. M. R. et al., 2020. Socio-environmental and land-use impacts of double-cropped maize ethanol in Brazil. Nature Sustainability 3(3), 209-216. doi: 10.1038/s41893-019-0456-2.

Moz-Christofoletti, M.A., Pereda, P.C., 2021. Winners and losers: the distributional impacts of a carbon tax in Brazil. Ecol. Econ. 183, 106945. https://doi.org/https://doi.org/10.1016/j.ecolecon.2021.106945

Rausch, S., Metcalf, G.E., Reilly, J.M., 2011. Distributional impacts of carbon pricing: A general equilibrium approach with micro-data for households. Energy Econ. 33, S20-S33. 
Sassi, O., Crassous, R., Hourcade, J.-C., Gitz, V., Waisman, H., and Guivarch, C., 2010. Imaclim-R: a modelling framework to simulate sustainable development pathways. International Journal of Global Environmental Issues, 10: 5-24. DOI 10.1504/IJGENVI.2010.030566

Schers, J., Ghersi, F., Lecocq, F., \& Grazi, F., 2015. Green Growth and its Implications for Public Policy-The Case of South Africa. Available at https://www.afd.fr/en/green-growth-and-its-implications-public-policy.

Silva, J., Gurgel, A., 2012. Impactos econômicos de cenários de políticas climáticas para o Brasil. Pesqui. E Planej. Econômico 42, 93-135.

Soummane, S., Ghersi, F., Lecocq, F., 2022. Structural transformation of the Saudi economy under global climate action. The Energy Journal 43 (3), 181-200.

Stiglitz, J.E.; Stern, N. (chairs), 2017; Duan, M.; Edenhofer, O.; Giraud, G.; Heal, G.; La Rovere, E.L.; Morris, A.; Moyer, E.; Pangestu, M.; Shukla, P.R.; Sokona, Y.; Winkler, H.; Report of the High-Level Commission on Carbon Prices, Carbon Pricing Leadership Coalition, supported by the World Bank Group, ADEME, Ministère de la Transition Écologique et Solidaire (France).

Taylor, L., Lysy, F.J., 1979. Vanishing income redistributions - Keynesian Clues about model surprises in the short run. Journal of Development Economics 6, 11-29. https://doi.org/10.1016/0304-3878(79)90033-6.

Timilsina, G.R., 2018. Where is the carbon tax after thirty years of research? The World Bank.

Timilsina, G.R., Shrestha, R.M., 2007. Alternative Tax Instruments for CO2 Emission Reduction and Effects of Revenue Recycling Schemes. Energy Stud. Rev. 15.

Tourinho, O.A.F., Motta, R.S. da, Alves, Y.L.B., 2003. Uma aplicação ambiental de um modelo de equilíbrio geral.Texto para Discussão. IPEA. Rio de Janeiro.

Van Heerden, J., Blignaut, J., Bohlmann, H., Cartwright, A., Diederichs, N., Mander, M., 2016. The economic and environmental effects of a carbon tax in South Africa: A dynamic CGE modelling approach. South Afr. J. Econ. Manag. Sci. 19, 714-732.

Van Heerden, J., Gerlagh, R., Blignaut, J., Horridge, M., Hess, S., Mabugu, R., Mabugu, M., 2006. Searching for Triple Dividends in South Africa: Fighting $\mathrm{CO}_{2}$ pollution and poverty while promoting growth. Energy J. 113141.

WayCarbon, 2019. Quantificação do potencial de geração de ativos de carbono através de atividades florestais. Available at: https://2bdc489b-111d-4176-8fda-

\section{9e5a9746d85.filesusr.com/ugd/12001a c4ddf603258f43278bbd1ec19baafb24.pdf?index=true}

Williams, R.C., Gordon, H., Burtraw, D., Carbone, J.C., Morgenstern, R.D., 2014. The initial incidence of a carbon tax across income groups. Resour. Future Discuss. Pap. 
Wills, W., 2013. Modelling long term effects of greenhouse gases mitigation policies in the Brazilian economy. Energy Planning Program (COPPE). Rio de Janeiro: Federal University of Rio de Janeiro (UFRJ). Available at http://antigo.ppe.ufrj.br/ppe/production/tesis/wills.pdf

Wing, I.S., 2006. The synthesis of bottom-up and top-down approaches to climate policy modeling: Electric power technologies and the cost of limiting US $\mathrm{CO} 2$ emissions. Energy Policy 34, 3847-3869.

Winkler, H., Delgado, R., Palma-Behnke, R., Wills, W., Salazar, A., 2017. Information for a developmental approach to mitigation: linking sectoral and economy-wide models for Brazil, Chile, Colombia, Peru and South Africa. Climate and Development 9(6), 559-570

Zhang, X., Guo, Z., Zheng, Y., Zhu, J., Yang, J., 2016. A CGE analysis of the impacts of a carbon tax on provincial economy in China. Emerg. Mark. Finance Trade 52, 1372-1384. 